反喣胃内繊毛虫類のアミノ酸および蛋白質栄養と

その反㫚胃内棲息の栄盖学的意義

小野寺 良次

宮崎大学農学部農業化学科, 宮崎市 880

\title{
Amino Acids and Proteins Nutrition of Rumen Ciliate Protozoa and Their Nutritional Significance of Inhabitation in the Rumen
}

\author{
Ryoji ONODERA \\ Department of Agricultural Chemistry, Faculty of Agriculture, \\ Miyazaki University, Miyazaki-shi 880
}

はじめに

反㫚胃内緎毛虫類は，宿主動物にとって何なのか？ この問題は, 反臅胃内に初めて織毛虫類が発見されたと き,すでにその発見者達 (GRUBY et DeLAFOND) によっ て意識されていた1). PASTEUR が植物性物質の発醉にお ける細菌の役割定確証した徯，ZUNTZは反蚠胃内微生物

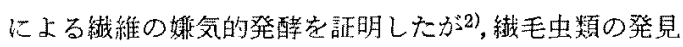
(1843)一反蜀胃内微生物の最初の発見一は,その 36 年 も前の出来事であったのである. 家畜の消化関吉る研 究存続けてきていた GRUBY et DELAFONDは，その時点 で，すでに，「反笏動物は草食動物である。しかし，反第 胃内峨毛虫類は植物性栄養素によって生育し，その結果， 植物性栄養素が動物細胞物質に転化され，それらの動物 細胞は，さらに，宿主によって消化されるのであるか ら，そらいら意味では，反筧動物は肉食動物である。」と 述べ，経験的に瀻毛虫類の宿主動物に対する栄養学的意 義について推論していた1). その後, 乾草浸出液等によ

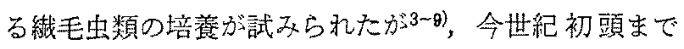
の結果では，いずれも失敗に終わっていた，その間，当 時の影微鏡でも十分観察が可能であったことから，織毛 虫類の形態打よび分類に関する研究は着実に発展した $6,10-18$ ).

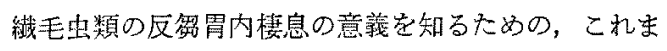
日蓄会報，46（12）：661-670.
での研究方法は二つに大別されよう。一つは，瀻毛虫類 の能力を間接的に検討しようとするもので, 具体的に

は，無緎毛虫動物在人工的敒り出し，乙の動物の生理 学的小よび栄養学的諸機能を対照の含瀻毛虫動物上比較 する方法をとるるのである。もう一つは，織毛虫類を反 㫚胃内から単離し, そのらの固有の諸能力を直接的汇検 討することによって，反男胃内での役割安推察しようと するものである。これら二つの方法による研究が本格化 し始めたのは，いずれも，1930 年頃と考えられる. 前者 については, BECKER ら"が, 反罚胃内に $2 \%$ 硫酸銅定注 入寸ることによって無䄉毛虫山羊を作成し，飼料中諸成 分の消化率等含織毛虫山羊と比較しているのがそれで ある.もっとも，無織毛虫動物作成の動機は，彼らに限 らず，当初，反蜀胃内一の織毛虫類の定着々感染源打よ び宿主特異性の梌討定志向していたことにあったようで ある ${ }^{14)}$ ，BECKER ら ${ }^{1}$ は，この実験に取り組むに当たり， それまでに提出されていた諸学者の緘毛虫観突次の6 項 目に整理し，それぞ机関して検討を加えている. (1) 反罚胃内織毛虫類は，自身をなげうって，植物性物質を より易消化な動物性物質に転化している。(2) 彼らは有 害な寄生虫である。(3)彼らは単なる無害な共生動物 (Commensals)である.(4) 彼らは宿主に害をるたらす Schizomycetes（分裂菌類：細菌）の增殖老抑制してい る. (5) 彼らはセルロースの消化を助けている. (6) 彼ら 661 1975. 12 . 
は反贸胃内容物の混合や粉砕などに関与し，機械的役目 を果たしている。しかし，BECKER らの結果は，上記各 項目のう方（3）項を除くいずれをも否定し，結局，瀻毛 虫類は単なる無益無害な其生動物之考学ざるを得ないと の結論に造しているただし，織毛虫類が「慨泥棒」か どうかについては更に检討を要するとしていた，これを 契機に，このような価織毛虫動物作成に上る存在意義の 検討は，兑の後多くの研究者によって続けられてきてい るが, 得られた結果は可否再論である。今後, 一層重視 されるべき研究方向であるう.これらの研究経過之問題

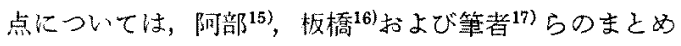
を参照されたい。

このように，間接的に織毛虫類の存在意義安検討する 研究は, やがて in vitro で正行われるようになった。

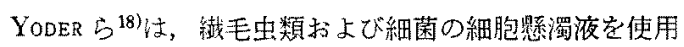
して，セルロースの消化安検討した結果, 瀻毛虫類のみ で約 7\%，細菌のみで約 $40 \%$ の消化萃を示していただ けなのに，絬毛虫類と細菌乙の混合系では，多い場合で 67\%の消化率老示すこ上を明らかにし，織毛虫類か企体 的に細菌の代謝活性是揚させること示唆した。

兴者,すなわち瀻毛虫類の諸能力を直接的に検討した 本格的な研究は， MARGOLIN ${ }^{19)}$ 以降に始まったと考方占

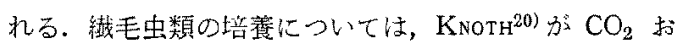
よびメタンを使用して娥父的条件䘮調製し， $\mathrm{pH} 6.8$ とす ることによって，107時間の培養に成功しているけれど む, 㵶毛虫類固有の代謝能力（特にセルロースの分解 能）の検討志志し，セルロース者含も培地で 14 口間 の培盖に成功している点では，MARGOLIN ${ }^{19)}$ 以降考克 てよいようである。 WestPHAL ${ }^{21}$ は，MaRGOLIN の研究 を参考にして，セルロースの消化を検討し，織毛虫類は セルロース分解しないと述べている. その後, HuNGATE ${ }^{22)}$ は渗透圧，pHおよび嫌気的条件を考虑して塩 類溶液を調製し, Eudiplodinium neglectum（反罚胃内 緎毛虫類の一種）によるセルロースの分解を記載し た.この種の研究における研究者の最大の悩みは, 緎毛 中類の培養時に細菌の混入が不可避であった点である.

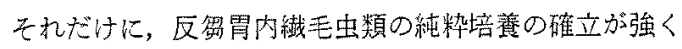
望をれてきたが，残念ながら今日なお，末確立のままで ある。最近，日野ら ${ }^{23)}$ は，化学的成分既知培地での瀻毛 虫類の增殖系培養空可能にしているので, 純䊉培養の確 立むそう遠いことではないであるう，とにかく，Hun・ $\mathrm{GATE}^{22}$ に上る塩類溶淮調製後は，瀻毛虫類をよく洗浄 後, その細胞慙濁液によって，また，抗生物質の量産後 は，乙れらを添加して混入細菌の影響を抑制することに よって，繊毛虫類の諸性質が多くの研究者によって検討
されてきた，それらの結果は，織毛虫類增殖柔で把握 したものではないが，それでも，反贸胃内における織毛 虫類の活動の推察を可能にする多くの筫料を提供してき た. それらは，すでに多くの総説にまとめられてい $ろ^{2,24-29)}$.

直接的湾織毛虫類の性質を検討した研究としては，上 記のような機能的側面たけに限らず，繊毛虫類を主宿の 栄養源と見る立場から，それらの栄養洒やアミ/酸組成 を検討したものがある．白ホズミによる反蜀胃内微生物 の栄養価判定試験によれば，生物価は菌体蛋白筫と虫体 蛋白質との間比差が認められないが，消化率は前者より も後者が高いので，正味蛋白利用率 (NPU) 注瀻毛虫類

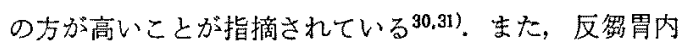
緎毛虫類の体蛋白質構成了ミノ酸としては, 細菌のそれ に比して, リジン含量の高いことが特徵である ${ }^{32-34)}$.

HORIGUCHI and KANDATSU ${ }^{35,36}$ は, 上記虫体蛋白質の丁ミ ，酸組成党検討中に, 自然界から始めて， C-P 結合をむ つ第三のてミノ酸といかれる2-ナミノエチルホスホン酸 (シリアチン)を榆出した．この物質它白ネ゙ミに高浱度 に投与してを，毒性は認められず，体内に吸収されて C-P 結合をつ新しい型の粼脂質 (Sphingophosphonolipids）が合成されることが示されだ8).今後，さらに， シリアチンの生理, 生化学的作用の解明が期待される.

本稿は，反翏胃内緎毛虫類に関するこれまでの知見を 全面的に総説するるのではなく，筆者らの研究経過を中 心に記述し，䋐毛虫類棲息の意義に言及することを主眼

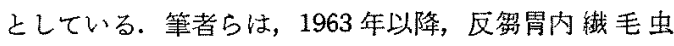
類固有の機能的側面，特に，フミノ酸拉よび蛋白質代謝 を検討するために，いかば”直接的方法”の立場から研 究に着手した。 その当時, すでに反燿胃内微生物の諸機 能の把握のためには, 微生物生態論 ${ }^{89 \sim 43)}$ 的思考方法の 必要性, 特に, 「微生物間の栄養源の争悪競合扔よび相 互利用を中心とした方法の導入副」が強調されていた。 これらの概念を基底にして，箻者らの研究が進められた ことを村言したい。

\section{I. アミノ酸栄養}

反㯡胃内の遊離了ミ/酸濃度は, 飼料給与後の時間に よって異なるが, 通常, $100 \sim 150, \mu \mathrm{gN} / \mathrm{m} l$ 程度存在す る44,45). これらは，飼料中の遊離了ミノ酸および微生物 による飼料蛋白質の分解産物火由来するるのと考えられ る、篻者らは, まず, 緎毛虫類の栄養源としてのこれら の遊離フミノ酸の重要度を知ることを始めの目的とし

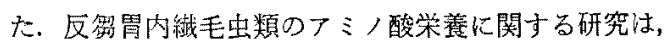
Williams Б ${ }^{46}$ 亿始まった。彼らは，塩類溶液中でOphr- 


\section{区势脅内緎毛中類の存在意義}

yoscolex caudatus 培養後, DL-Val-4-14C, DL-Ala ${ }^{2-14} \mathrm{C}$ および DL-Leu-2-14C が虫体内に濃縮されること 䓘認めた. Epidinium ecaudatum についても同栐の結

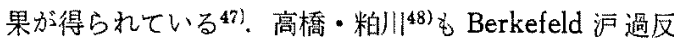
第骨内液によって，Entodinium 岩主体と寸る混合䋐毛

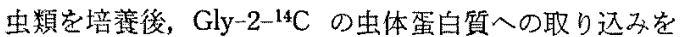
確認した。同時に，彼らは各種つミノ酸定個々に添加し て，繊毛虫類による各てミ，酸の消費量をハシンスライク 法で検討した結果，Pro および Metを除く各種つミ， 酸加消費されて，アンモニアが生成されることを示し $\star^{48)}$. これに对して, ABOU AKKADA and HowARD ${ }^{49)}$ は, カゼイン加水分解物定加えた緩衝液中で Entodinium穵 培養しても，虫体内に組み込ま礼るつミ，酸量は無視 出来る程度であり，無基質で培養した場合は，6時間後 に，虫体 $\mathrm{N} か ゙$ 約 $6 \%$ 減少して，非蛋白態 $\mathrm{N}(\mathrm{NPN})$ とな

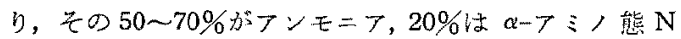

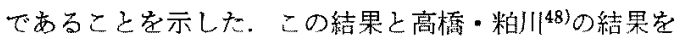
統一的に説明することは困難であることから，等者らは まず，瀻毛虫類によるアミ／酸の消費をバンスライク検 生法によって追試した．瀻毛虫類の培地としては，「対象 のもつ自然的な性格を可能な限り生がす42 」ために，ザ イッ沪過反算胃内液を使用し，これに $50 \mu \mathrm{g} / \mathrm{ml}$ のディ ヒドロストレプトマイシンサルフェートおよび $10 \mu$ mole $/ \mathrm{m} l の \mathrm{Glu}$, Met およびLys 老個々に添加して, GUTIERRE $Z^{50}$ の緩衝㖡で 5 回洗浄した混合織毛虫類 24 時間培莘した。その結果，いずれのアミノ酸添加した

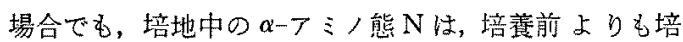
養後に高くなり，この方法では，フミノ酸消費量の検討 は不可能であることが分かっだ1)。なお，この結果は ABOU AKKADA and HOWARD ${ }^{40)}$ の結果と一致するもので あった，高橋・粕川148) は，抗生物質使用しないで20時

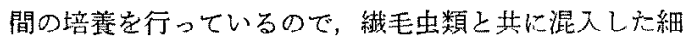
菌の増殖によって, 結果に相遠が生じたものと推察され た、反蜀胃内細菌によるアミ，酸の分解については多く

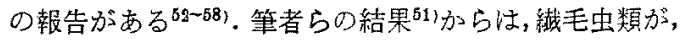
培養中，培地中に $\alpha$ アミノ態 $\mathrm{N}$ 增加させるものと考え

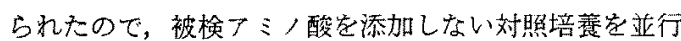
し，対照培糞および被検アミ，酸添加培養各区のそれぞ れの堷善前後のアミノ態Nの差の, 更に, 各区間の差を 求めて，被検乃ミ／酸の消費量とすることにした，その 結果，見かけ上Glu，Try，Lys，Hisなどはよく消費さ れたが，Asp，Val，Ala，Arg，Pheなよ゙はまったく消費 されなかっだ1)。また，繊毛虫類・細菌の共存培養時の フミ，酸消費量は，各微生物の単独培養時のそれよりも 見かけ上小さい值となった，この原因は，被検了ミノ酸
消賴量の低下によるものではなく，繊毛虫類による細菌 の捕食分解産物としてのてミ，態Nの堌加に上るものと 推察された 中に添加したてミノ酸の蕒の動き炎検討した。瀻毛虫類

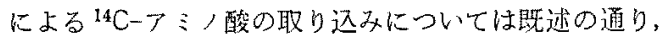

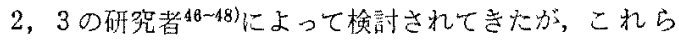

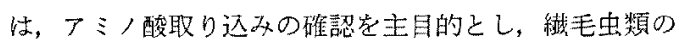
N策養源としてのフミノ酸の重要度には言及していな い. 筆者らは，纎毛虫類と細菌とのアミノ酸取り迄み量 の比较および緎毛虫類と細菌との共存時のアミ/酸の動 きに注目しながら検討し，次のよらな結果を得た（1) バンスライク㭘圧法の結果51 では見かけ上消費されな かった各了ミノ酸も虫体内に取り込まれ，量的には，虫 体蛋白質成分中に少ないMetが多く取り込まれ，逆に， 蛋白質成分中に多いGlu，Lys およびAspは取り这み 量が少なかった。（2）緎毛虫類・細菌共存培䁈時に菌体

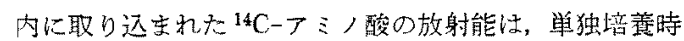
に虫体太に取り込まれたそれの2〜10倍であり，培地中 の ${ }^{14} \mathrm{C}-$ アミ/酸の放射能は，3時間培養後, 前者で, 始 めの 24.2 83.9\% 減少したのに対して, 後者では，0〜

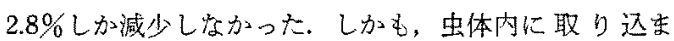
れた放射能は，単独培養時よりる共存培養時の方が常に 高い值を示した59. したがって，虫体内にすてミ／酸は 取り迅まれるけれども，その量は，細菌による取り迟み 量よりもかなり少ないことおよびアミ，酸を取り込え だ菌体は続いて繊毛虫類に捕食されると推察され，その 場合の方が虫体内に移行するてミ，酸量が多いことが分

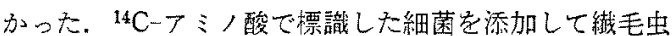
類を培養すると，放射能恃虫体内に移行し， 3 時間目に 最大となった。このとき虫体内に取り込まれた菌体 $\mathrm{N}$ 量

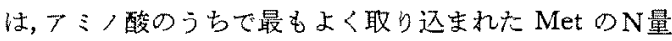
の約 20 倍であった ${ }^{59}$. 以上の結果から,瀻毛虫類の主要 なN栄養源は，遊離のアミ/酸よりも細菌などの粒状物 質であるうこと，扎よび，フミノ酸の虫体内への主要な 移行経路として「アミ/酸 $\rightarrow$ 細菌 $\rightarrow$ 緎毛虫」という食物 連鎖が存在することが推繁された ${ }^{59,60)}$. 同じ垻 COLEMAN

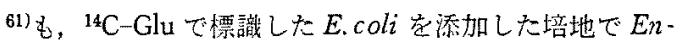
todinium caudatum を培斏し，48時間後に，添加菌体 の97\%が代謝され，始わの放射能の $28 \%$ が虫体内に保 持された事恶加ら，E. caudatum にとって遊離 酸よりも菌体の捕食によって得られるてミ/酸の方が有 効であらうと推察した。

\section{II. 食物摄取样式}

古くから，反罚胃内瀻毛虫類の体内に植物片の陉取加 


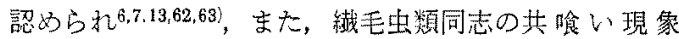
(Cannibalism) も知られて㧍り ${ }^{64.65)}$ ，瀻毛虫類による 粒状物質の捕食についてはよく観察されていた，一方， Isotrichidae 科に属する3 種の緎毛虫類は,グルコース,

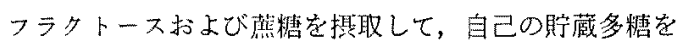
形成することが認められ とが明らかになった。 その徯, Ophryoscolecidae 科の一 属である Entodinium は好んで敗粉粒を摂取し, 揮発性 脂肪酸 (VFAs)， $\mathrm{CO}_{2}, \mathrm{H}_{2}$ お゙び微量の乳酸孝産生する

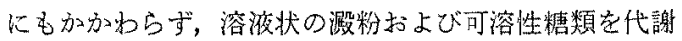
しないことが示され67)，立た，同科に属するOphryoscolex の栄荃源上しても粒状物犋が必須であることが認め

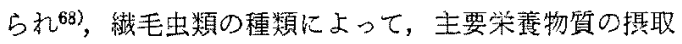
様式が暴なるここが示唆された。

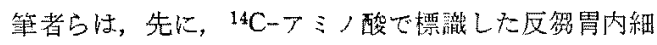
菌を培地に添加して瀻毛虫類を培䒾した場合, 虫体内に 高い放射能が検出されたことから，驖毛虫類による細菌 の捕食を推察したが，ここでは，フクシンで染色した網 菌を培地に添加して，菌体の虫体内人の移行の様相を実

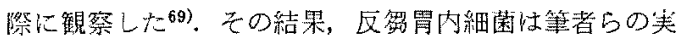
験条件下でも，あらゆる種類の瀻毛虫によって捕食され ることが分かった，瀻毛虫類は，始か，繊毛を使ってロ 腔内に多数の細菌定集め，一定量に達すると食胞を形成 して体内に送り込んだ，その間約 15 秒であった，続い て，の他の粒状物質の捕食について子検討し，染色酵 母同樣あらゆる種類の緎毛虫類によって捕食されるこ とを認めた ${ }^{69)}$. Isotricha 属によるクロレラの取り迄み は，葉緑素の变色により，確認方困難であった todiniinae 去よび Diplodiniinae 各再科 ${ }^{70)}$ に属する緎 毛虫類は, 染色セルロ一ス粉末および炭素粉末起取り込 えだ69)。炭素粉末の摄取は，これらの緎毛虫類が，掑取 に当たって，粒子の栄䖯性を嚴密には区別していないこ と示唆している. MULLER ${ }^{71}$ は，Paramecium およ び Tetrahymena による Polystyrene latex particle の 取り込双について報告している。 GutIERREZ $Z^{72)}$ および Gutierrez and Davis ${ }^{73)}$ は, Isotricha, Entodinium お よび Diplodinium が,特定の細菌苍選択的に取り込むと 述ベているが，彼らの実験は，細菌取り迄正後の虫体を 破壊し，その中に含まれる生菌種を検討したものであり，

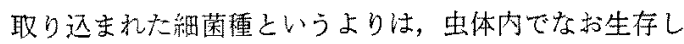
ていた細菌種之考えるへきものであるう。COLEMAN $\left.{ }^{61}\right)$ は, 虫体内で易消化な細菌と難消化な細菌とがあることを報 告している. Minato $5^{74)}$ 性，反忽胃内細菌の局在性に ついて, 例えば, Bacteroides amylophylus などは, 激 粉粒に対方る付着性が強く，その表面に密集することを
報告しているが，そのような場合には，虫体による搌粉 粒掑取に伴い，虫体内に B. amylophlusなどが特に多く 搷取されることはありうることであるう。

統いて，筆者らは，溶液状物質の掑取に関して若干の

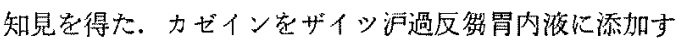
ると、コロイド状に溶解する。このような溶液执の力ゼ インは, Isotrichidae 科の絨毛虫類によって速やかに分 解されたが，Ophryoscolecidae 科の繊毛虫類によっては 全く分解されなかっった ${ }^{75)}$. CHALMERら ${ }^{76)}$ の方法に往。 て，力ゼインを難溶性とし，粒状にして与えると，Opryoscolecidae は，速やかにこ蛇分解した75)。したが。 $\tau$, Ophryoscolecidae は，可溶性糖類の場合 ${ }^{67.77)}$ と同様 に，溶液状蠧白質をも分解せず，溶液状物質它経口的に は提取し得ないものと考えられた。また，これらの織毛 虫類は，経口的に精状物質它拱取する際でも，同時にそ の培地に溶存している物睤它，通常，経口的には掑取し

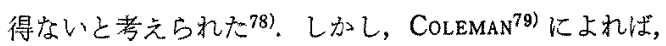
荷電粒子などの場合，溶存物質がそれに吸着される性質 があれば，同時に溶存物質手掑取される。このように，

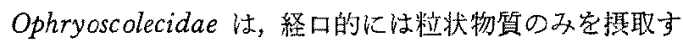

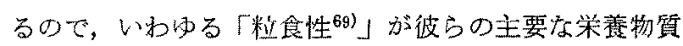
の摄取様式である己考えられた。摄取される粒子は必ず しも固形物に限らず，たとえば，オリーブ油の微滴も Entodinium caudatum によって取り込まれ80)，なた， その他の緎毛虫類についても取り込みが確諗されてい $\zeta^{81)}$.

他方，前項で述ベたように， ${ }^{14} \mathrm{C}$ 標識厂ミノ酸は，溶 液状であるにもかかわらず，Ophryoscolecidae 体内に取

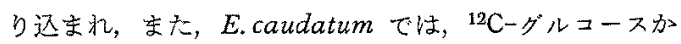
らのガス生成量がグルコースを添加しない対照区のそれ

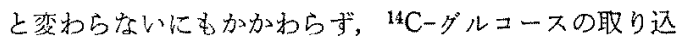
みが確認されているので82，Ophryoscolecidae に上る溶 液状物質の掑取が皆無でないことは明らかである。この 点について, COLEMAN ${ }^{82)}$ は, 低分子の溶液状物質が細胞 膜から掑取されることを指摘し，その場合，外質膜の透 過性は大であるけれども，外質膜之内貿膜の間にある障 壁が低分子物質の内質への透過を妨げるために代謝堂う けにくくしているのではないかと推察している. 外質中 で注代謝されにくい82)にもかかるからす，筆者らの実験に よればアアミノ酸はある程度，Ophryoscolecidaeによっ て代謝されるので83)，低分子物質でるとの理化学的性質 によって, 内質膜付近の障壁の透過性が異なるむのと推 察される ${ }^{78)}$ ，溶液状でむ，既述のように，蛋白質のよう な高分子物質の膜透過による提取は考えにくいが，どの 程度の分子量の物質までが透過されるかは不朋である. 


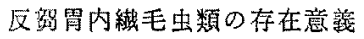

\section{III. 蛋白質代謝}

反虽胃内織毛虫類による蛋白質の代榭に関しては，す

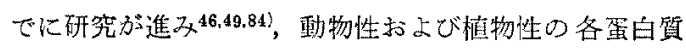
は，E． caudatum および混合織毛虫類によって分解さ れ，ペプチドアアミノ酸拉上びアンモニアを生成するこ 上が認められ每,84), 更に, E. caudatum のプロティナー ゼおよびベブチダーゼがある程度精製された

筆者らは，前述の上うに，Ophryoscolecidae が溶液状 のカゼインを分解せず，加熱变性させた粨状力ゼインの 双を分解するのに対して, Isotricha は, 溶液状の力ゼ インをも分解することを明らかにした75. 艺の場合， 5 持間培養後の分解産物は, Ophryoscolecidue 枋上びIsotrichidae で，アンモニフ態Nが，NPN の，それぞれ， 12.8 柇よび15.6\%，アミ/態Nが, 28.7 および $17.3 \%$, ペブチド態Nが， 52.5 おび $43.6 \%$ あっって、いずれの 場合もぺプチドの占める割合が極めて大きいことから， 虫体内に括当蛋白質の消化が不完全であることを推察

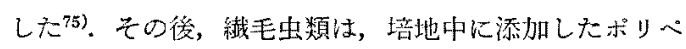
プトン（カゼインのパンタレアチン消化物）是分解し

て、アミノ酸就よ゙゙アンモニアを生成することを明らか にすると共に，カゼインの分解によって生成したペプチ ドは，培養 3 時間目に，Ophryoscolecidae およびIsotr . ichidae で，それぞれ，35.7および46.9\%であったもの

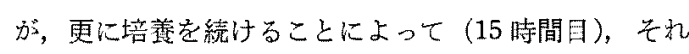
ぞれ，10拈よび5\%に減少し，その時，主にアミ，酸 の占める割合が，艺れぞれ，47.1および57.7\%と大きく なること军明らかにした85).この上うに, Ophryoscoleci一 dae のみの場合でも，Isotrichidae を合む場合とほぼ同 様の結果が得られていることから，これらの虫体が膜透 過によってペプチドを体内に取り远み，体内でそれを分 解したのか，それとも，体外にベプチダーゼを分泌して 分解したのかが，食物摄取椂式を知る立場からも問題に なるところである.この点に関しては, 緎毛虫類懸濁

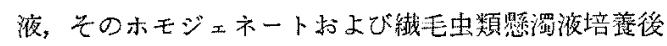
(5 時間)の上澄液の各々によってポリペプトンから生 成されたアンモニア態Nに対するアミノ態Nの比が, 前 2 者 (3.9 5.1) に比較して, 後者 (上澄液) (12.8 26.0) で著しく高い事実から，織毛虫類はへプチダーゼを体外 に分泌している可能性がある己推定した ${ }^{85}$. しかし，膜 透過によるポリペプトン摄取の可能性は必ずしも否定さ れていない。

続いて, このように，カゼインの分解によって生成し た培養液のフミノ酸パターン(MAA)を，織毛虫類の内 因性厂ミノ酸パターン(EnAA, 次項で詳述)およびカゼ
インの檏成フミノ酸パターン(CAA) と比較した結果, MAA ではLeuが最多く，続いて Glu多多かったが, Leuは，CAA中では 3 番目に多いものであり，また, En AA中では10番目に多いアミ/酸であって，EnAA中に 最む多いAla はMAA中では6留目に多いアミ/酸であ った。全体的に見ると，MAA は，EnAA 拉よび CAA の影響をうけながらむ，それらとは買なったパターンを 示したので，カゼインの分解によって生じたアミ，酸 は，虫体内の代謝にそれぞれ特有な㥞式によって関与し

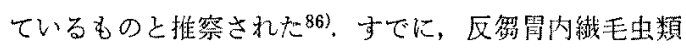
の蛋白質の合成についても，放射性同位元秦で標諳した アミノ酸の使用により袷討され始妨打り ${ }^{87,88)}$ ，分解の 問題と合和せて，いずれ，纎毛虫類の蛋白質の代謝様式 が解明されるであるう。

\section{IV. アミノ酸代謝}

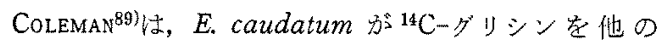
物質に転化することなく，钝まの形で自己の体蛋白 質中に組改込む其に，虫体細胞“プール”中では，Nアセチルダリシンの形で保持していることを示した。 そ の他の 11 種類のアミノ酸についても, 同栐に, 虫体蛋白 質中にはとのままの形で組み込まれ，培视液および細胞 “プール”中ではVFAsおよび N-アセチルをたは N-ホ ルミル誘導体に転化して存在していることが示された 79). Isotricha spp. ${ }^{90)}$ および E. simplex ${ }^{91}$ Kついても類似 の検討が行われている. HARMEYER ${ }^{92)}$ は, フミ酸混合物 を添加して Isotricha spp.を培養し，Arg おょびCys以 外のフミノ酸があまり分解されないと述べている.

筆者らは，具体的空了ミノ酸代謝の顺討に入る前に， 当初の実駼で51)，繊毛虫類培盖後の培地中のアミ，態 $\mathrm{N}$ が培養前のそれよりも常に高くなることをまず問題に し，それらのてミノ酸ハターンの検討它行った，当初使 用していたザイッ沪過反虫胃内液中にはつミノ酸が含ま れているので，ここでは，人工紘哂液を使用することに した，それまで，多くの研究者によって試作された緩衝 液22,50,84,93-99)は，大同小異であって，最大の間題は緩衝 能が弱いために培蒦中に $\mathrm{pH}$ を再調整せ称ばならない ことであった、筆者らは, 神立・高橋の緩衝液84)基に

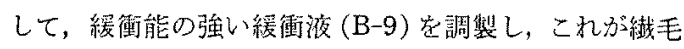

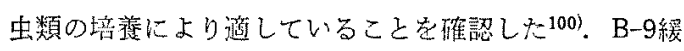

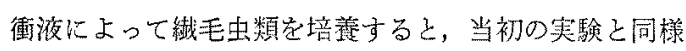
に，培地中にアミノ態Nが增加した ${ }^{101)}$.これらのアミ， 酸は, 繊毛虫類の死滅に伴う虫体内遊離 や自己消化によるものでなく，内因性の代謝産物で西る ことが示された101)、B-9緩衝液中で混合瀻毛虫類荙 12 
時間培管すると，虫体N成分が約 $22 \%$ 減少し，培地中に NPNが增加したそとのうち、フンモ二フ態Nおよびア ミノ態Nは，それぞれ，44.8および43.8\%を占め，雨皆 はほぼ同值であった1011).次に，これらの内因性了ミノ酸 パターンを検討した結果，Alaが最も多く，次いでGlu， Proの順に多かったそして，これら 3 種のアミノ酸だ けで，内因性アミノ酸全体の約 65\%を占好ていのが 特微であった．また，もう一つの特徵は，Arg 拉よび Cysがほとえど検出されなかったことである1011. その後 の梚討によれば，内因性丁ミノ酸パターンは，糖質添加 によってAla が增加するなど培篦条件または虫体の状能 によっで102)，また，Entodinium おょび Dasytricha な ど小型虫体の多い場合に Gluが多くなり，Epidinium, Ophryoscolex お。よ゙ Isotricha など大型虫体の多い場 合に Ala が多くなるなど，綫毛虫類の種類によっても 103)，乙れでれ買なることが示された。 HARMEYER ${ }^{104)} は$ は, Isotrichaについて同栏の检討をし，24 時間の培養で， 虫体N成分の $25 \%$ 唯減少し，培地中N成分の $30 \%$ が ミノ酸で, とくに, Ala, Glu, Asp, Pro が多く, その他 に、シトルリンおよびオルニチンが検出されたと述べて いる. 筆者らも，上記内因性フミノ酸の洰紙クロマトグ ラム中に蛋白質構成アミ，酸以外に 6 種類のニンヒドリ ン陽性末同定スポット (US-1〜US-6) 莨検出した ${ }^{101)}$. 次に, これらの未同定スポットのうち, 始めに, US-1

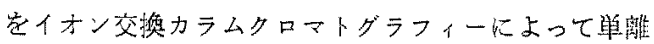
し, 水・エタノール・エーテル采で針状結唱を得, その 元素分析, 質量分析, 赤外線吸収スペクトル，融点およ び比旋光度測定および沪紙クロマトグラフィーによ。 て，これがL-(-)-ピペコリン酸であることを決定し た ${ }^{105)}$. ピペュリン酸は, ZACHARIUS $ら^{106)}$ によって, 植物 の種子加ら検出され，その後の研究では，これが白ネズ ミのリジン代謝における中間代謝産物であることが示さ れたが107，やがて，白不スミでは，D-リジンの代謝産物 であることが明確にされた ${ }^{108) .}$. 微生物関倸では, Euglena gracilis によるピペュリン酸からのリジン合成 ${ }^{109)}$ お よび Pseudomonas putida によるリジンの代謝産物110) の証明がある. 反氛胃内微生物関係では，反臅胃内から 単離した E. coli がリジンを分解して等モルの醋酸的よ

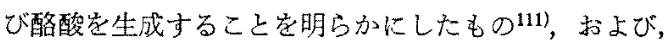
反忽胃内混合細菌がリジンからすーフミ吉草酸および

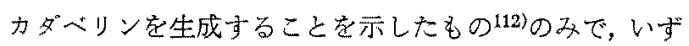
れる細菌に開するものであった。筆者らは，ピペュリン

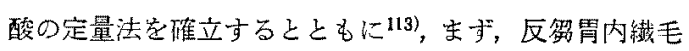
虫類が何からピペコリン酸索生成するかを梌討した83). その結果，B-9緩衝液中で維毛虫類を 24 時間培養する
と，培地上清中に菩䅡したピペエリン酸のモル濃度は， 虫体蛋白質中リジンの減少モル浱度とほぼ一致し， た，培地中にリジンを添加した場合のみ，〕ミノ酸定添 加しない対照区よりもピペコリン酸生成量が多くなるこ

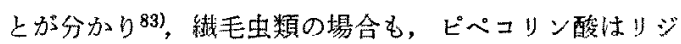
ンから生成されるものと推定された，続いて，Lーリジ ソ-U-14C 培地に添加して瀻毛虫類を 6 時間培養した 結果，明らかに培地上清中に放射性のピペコリン酸が検 出され，比放射能から算出したその量は，Isotrichidae を含を混合虫体小よび Ophryoscolecidae のみの場合で それぞれ，0.053拉よび $0.062 \mu \mathrm{mole} / \mathrm{ml}$ であった.この とき虫体内には，弚机ぞれ，0.056 および $0.048 \mu \mathrm{mole} / \mathrm{m} l$ のリジンが他の物質に枟化されることなく取り込をれて いた ${ }^{83)}$. 放射性のビべニリン酸を添加して緎毛虫類を培 養しても、ピペコリン酸はまったく変化をうけなかった

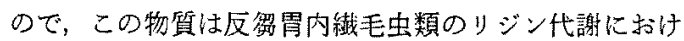
る終末産物であると考元られた ベコリン酸が生成する場合の機序を知るために Lーリジ ソ-2, 6-15 $\mathrm{N}$ を添加して緎毛虫類を培養した結果， ${ }^{15} \mathrm{~N} の$ 多くは，ピペコリン酸々フンモニフ画分に検出され，フ ミ/基転移反応に関与するアミ，酸中には極微量検出さ れただけだったので，ピペコリン酸は，リジンのミーナミ /基の転移反応によってではなく， $\alpha-$ ○基の酸化

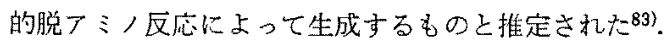

続いて，筆者らは，反得胃内瀻毛蝢のリジン合成能 の検討を行った，先にも述べたように，繊毛虫体蛋白留 は, 細菌体蛋白質に比して,リジン合量の高いことが特 徽の一つであるが32-31)，樴毛虫類のリジン合成能につ いては，一般的に否定的であった，それは，VOGELらが 此較生化学的観点から一連の実騟を行い,「動物細胞任 リジンを合成しない.」114) と提唱し，これがある程度定 説化していたからであった，しかし，その後，GUTTMAN ${ }^{115)}$ は, 16 種類のトリペノゾーマ科の顴毛虫類のうち 9 種類が、リジンの代りに $\alpha, \varepsilon$-ジフミノピメリン酸(DAP) を含む培地でも生育することを示し，これらの鞭毛虫類 が DAP名らリシン定成しうることを示唆した。 しか し, 彼らは, DAPからのリジン合成能を, 直接証明し てはいなかった.一方, HARMEYER und HEKIMOGLU ${ }^{116)}$ は, 4 種類の反忽胃内瀻毛虫類它醋酸-2-14C と共に培養後, 虫体蛋白質中の他のアミ/酸と同梯に，リジンにも微量 の放射能を検出した．箻者らは，まず，DAP-1，7-14C を培地に添加して混合瀻毛虫類を 12 時間培莨した結果, $2,117 \mu \mathrm{mole} / \mathrm{m} l$ のリジンが生成され，そのう方約 $9 \%$ さらにピペコリン酸比転化されていることが明らかにな っだ17). 生成されたリジンからはピペュリン酸のみが次 


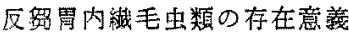

の代謝産物として検出され，その他の画分には放射能が 検出されなかったので，DAPからのリジンの生成は, 細 菌によってではなく，織毛虫類自体によって行われたと

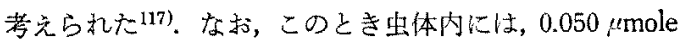
$/ \mathrm{ml}$ のリジンが組及込まれていだ17)。また, Entodinium とDiplodinium との間にはリジン合成能に差弥認めら れなかった118). 次に, 細菌、藻類就よ゙高等植物などの リジン合成 (DAP 経路) の出発物質である L-Asp-U-14C 扣よひ醋酸ナトリウムーU-14C からのリジン合成量を蟣 毛虫類で検討してみると，いずれからも無視出来る程度 のリシンしか検出されなかったので，反第霄内緎毛蝢 は，すでに，DAP 合成能定失っているむのと推定され

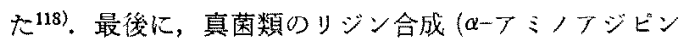
酸 (AAA) 経路) の前駆物質である DL-AAA - $6^{-14} \mathrm{C}$ 湑

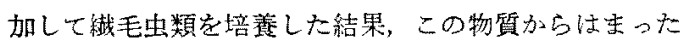
くリジンが合成されなかっだ机．以上の結果から，反第 胃内繊毛虫類は，DAPからのリジン生成能定保持して はいるが，DAP の合成能はすでに失っていると若兑ら れた。

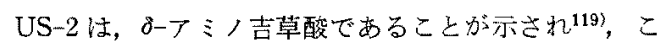
れは緎毛虫類によるPro代謝の終末産物であると推定

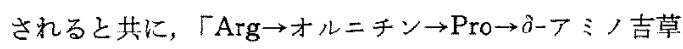
酸」という一連の代謝経路が明らかにされた ${ }^{120)}$ ，また，

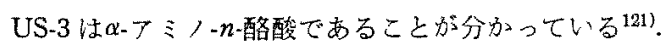

\section{V. 緎毛虫類棲息の意義}

既述のように，緎毛虫類の体蛋白質構成フミノ酸は， 細菌のそれに比してリジン含量の高いことが特徵であ

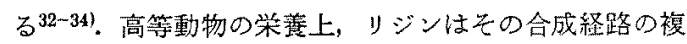
雑さに起因して，必須厂ミノ酸の中でる特に必須性の高 いアミノ酸であることか゚知られている. また, 白六ズミ による繊毛虫体の正味蛋白利用密は，細菌体のそれより も高いことが指摘されている30.31). N栄養の面からは, 主に以上の結果にもとついて㴍毛虫類の反留舅内棲息の 意䤜加推察さ㣗てきた。

筆者らは，前項既述のように，反羁胃内緎毛虫類の DAPからのリジン生成能を明らかにすると同時に、瀻毛 中類が DAP 合成能をすでに失っていることを示した 118)。したがって，䄉毛虫類は，反罚胃内において，何か から DAPの供給を受けているに違いない上考えられ

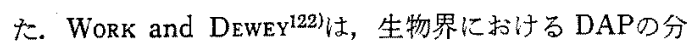
布を検討し, 118 種の細菌のうちグラム陽性球菌, Streptomyces spp. および Actinomyces spp. 以外の細菌およ び藍藻類にDAPを稌出したが，他の藻類，真菌類，植物 ウイルス㧍よび原生動物には検出でき度かったと述べて
いる，その㣪，DAPは，グラム陽性ふよび陰性細菌に広 く分布し，それらの細菌細胞壁のぺプチドグリカン中の テトラペプチド縜 (L-Ala-D-Glu-L-Lys (or meso-DAP) -D-Ala) の中に組み込まれていることが示された ${ }^{233) . . ~}$ 通常，テトラペプチド鍞中の二湓基性厂ミノ酸は，Lーリ ジンまたは meso-DAPであるが，ま机に、オルニチン， 2,6-ジフミノー3ーヒドロキシビメリン酸または 2.4-ジフ

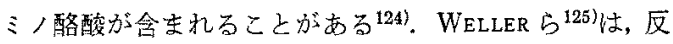
繁骨内混合細菌のDAP 含有量加, 菌体総Nに対する DPA-Nの百分率で示すと，0.57〜0.64\%であること索 明らかにした。しかし，これまでの知見によれば，細菌 細胞壁中のぺプチドダリカンは，トリプシン126), ペプシ ンまたはキモトリプシン127によっては消化されで，また， 正常な辛の及荈置内で生育した細菌のぺブチドダリカン は，その小腸内ではすったく消化されないこ上が示さ れ，さらに，羊の体内に注入された DAP それ自体も代 謝されることなく尿中に排泄されることが示された ALLISON ${ }^{129)}$ は，細菌細胞壁の消化が困難であることか ら，その中に含まれる非アミ，態むよびアミ／態Nは恐 らく徨主動物にとって栄盖価値をもたないだるうと述心゙ ている.しかし，絓毛虫類による細菌の捕食はよく知ら れた事实である61,69,72,73、130 133).

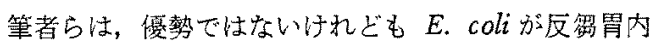

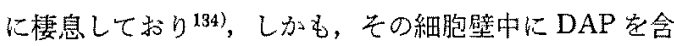
有していることが知られているので135)，これ定山羊の 反㮶胃内から単離し，10 $\mu \mathrm{Ci} の \mathrm{DAP}-1,7-{ }^{14} \mathrm{C}$ および 5 $\mu \mathrm{mole} / \mathrm{m} l$ の-リジンを添加して純粋培营を行い，放射 性の DAP 合む $E$. coli の細胞壁を得た ${ }^{136)}$. この細胞 壁中に含まれる放射能の $95.0 \%$ DAPであり，2.1\%か リジンであった. 得ら机た E. coli 綪胞壁添加して瀻 毛虫類を 6 時間培養後, 培養液を加水分解して, その沪 紙クロマトグラムのオートラジオグラム荌検討した結 果, 多量のリジンの生成が認められ，艺の他に，明確な ピペコリン酸のスポットが检出された。この時, 添加し

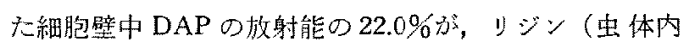
リジンを含む）打よびピペコリン酸に転化していた。 た，リジンの代謝産物としては，ピペコリン酸しか検出 さ礼なかったので，この場合のリジンの合成は明らかに

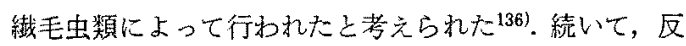
蚠胃内混合細菌およびその細胞壁を加熱処理後,これら をそれぞれ添加して繊毛虫類を6 時間培養した結果，前 者からは少なくとも $0.351 \mu \mathrm{mole} / \mathrm{m} l$ の，また後者から は少なくとも $0.641 /$ mole $/ \mathrm{ml}$ のジンがそれでれ生成 されたと考兵られた136)。以上の結果から，緎毛虫類は，

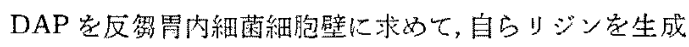


しているものと考えるれた。また, 細菌細胞壁のペプチ ドダリカン中にDAPの代りにリジンが含机る場合も， 同様に瀻毛虫類によってペプチドダリカンが分解され， リジンの利用可能な状態が作り出されるものと考えられ た。したがって, 反翏周内に瀻毛虫類が椿息している限 り，細菌細胞壁は決して宿主動物に上って抯益ではな く、兑しろ,リジンの生成源として有益で亦ると考れられ た、すでに，羊を使った実験でリジンが無瀻毛虫動物 の制限アミ，酸になることが示されており ${ }^{137.1988}$ ，宿主動 物に対するリジンの供給面で反侽胃内織毛虫類が果たし ている役割は極めて大きいと考えられた。

$$
\text { おわりに }
$$

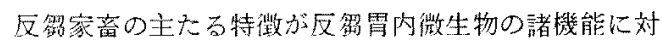
する摍主の依存であるうことは言をまたないところであ

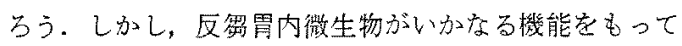
いるかということになると，その全貌はまだまだ解明さ れていない部分が多い。

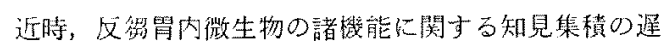
滞にたまり兼衫てか，宿主の微生物に対する依存己いう 特徵を無視した飼育法が指導され，多くの問題を生多出 しているように見うけられる. 単に採算が合えばよいと いうことでなしに，反得家畜の特徵を生かした真の価值 の生産性の増大を計ること污㥛めて重要なように思われ る.その基礎として, 反得胃内微生物の諸機能に関する 資料が，位って，そのための研究者が一層数を增すこと 加期待される。

本稿は, 昭和 50 年度 (1975) 日本畜産学会賞受賞講演 原稿に加筆したものである。

\section{文献}

1) Becker, E.R., J.A. Schulz, and M.A. Emmerson, Iowa State Coll J Sci 4: 215-241. 1930. より.

2) Hungate, R. E., "The Rumen and Its Microbes", Academic Press. New York and London. 1966.

3) Coste, M., Compt Rend Acad Sci 59: 149-155 1864.

4) Edwarns, M., Compt Rend Acad Sci 59: 155156. 1864.

5) Pouchet, F. A., Compt Rend Acad Sci 59:276 -283. 1864.

6) Schuberg, A., Zool Jahrb 3: 365-418, 1888.

7) Certes, A., Bull Soc Zool France 14: 70-73. 1889.

8) Guenther, A., Z Wiss Zool 65: 529-572. 1899.

9) Becker, E.R., and M. TAlbott, Iowa State Coll J Sci 1: 345-373. 192\%.
10) Stein, F., Abhandl Kais Boehm Ges Wiss 1858.

11) STEin, F, Lotos 9: 2-5. 1859.

12) Stein, F., Lotos 9: 57-60. 1859.

13) Dogiel, V.A., Arch Protistenk 59: 1-288. 1927.

14) Becker, E. R., and T.S. Hsiung, Proc Nat Acad Sci 15: 684-690. 1929.

15）阿部又信，獣音新報 629：18-22. 1974.

16）板橋久雄，策養生理研究会報 19：39-50.1975.

17）小野寺良次, 獣竞新竍 628: 1258-1262. 1974.

18) Yoder, R. D., A. Trenkle, and W. Burroughs, J Anim Sci 25: 609-612. 1966.

19) Margolin, S., Biol Bull 59: 301-305. 1930.

20) KNoth, M., Z Wiss Biol Abt F 1: 262-282. 1928.

21) Westphal, A., Z Parasitenk 7: 71-117. 1934.

22) Hungate, R. E., Biol Bull 83: 303-318. 1942.

23) Hino, T., M. Kametaka, and M. Kandatsu, J Gen Appl Microbiol 19: 397-413. 1973.

24) Oxford, A. E., Exp Parasitol 4: 569-605. 1955.

25）堀口雅昭 - 久保辰雄 - 神立 誠, 栄薪障害研究会 報 7: 93-121. 1963.

26) Hungate, R. E., M. P. Bryant, and R. A. Mah, Ann Rev Microbiol 18: 131-166. 1964.

27) 神立 誠, 乳牛の科学 梅津元昌編 174-185. 農文協. 東京. 1964 .

28) Grain, J., Ann Biol (Paris) 6: 17-45. 1967.

29）湊一一植村定次郎，発醅之微生物 III 植村 相田編 198-299. 朝倉車店. 東京. 1970.

30) McNaught, M. L., E.C. Owen, K. M. Henry, and S. K. KoN, Biochem J 56: 151-156. 1954.

31) Bergen, W. G., D. B. Purser, and J. H. Cline, J Dairy Sci 51: 1698-1700. 1968.

32) Weller, R. A., Aust J Biol Sci 10: 384-389. 1957.

33）堀口雅昭, 博士論文 東京大学. 1960.

34) Purser, D. B., and S. M. Buechler, J Dairy Sci 49: 81-84. 1966.

35) Horiguchi, M., and M. Kandatsu, Nature 184: 901-902. 1959.

36) Horiguchi, M., and M. Kandatsu, Bull Agr Chem Soc Japan 24: 565-570. 1960.

37）玉利正人・堀口雅昭 - 神立 誠, 日農化誌 45: 433-440. 1971.

38) Maget-Dana, R., M. Tamari, J. Marmouyet, et L. Douste-BlazX, Eur J Biochem 42: 129134. 1974.

39) Hungate, R.E., Ann Rev Microbiol 4: 53-66. 1950.

40）槒村定次郎，日農化誌 31：A93-A98. 1957.

41) Hungate, R. E., Bacteriol Rev 24: 353-364. 1960.

42）植村定次郎・古坂澄石・須藤恒二, 微生物実験法 : 微生物工学講座 2 . 友田・坂口・山田・朝井共 編 160-220. 共立出版. 東京. 1962 .

43）植村定次郎，科学 33：408-413， 1963.

44) Annison, E. F., Biochem J 64: 705-714. 1956. 


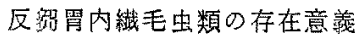

45）常䚀憲司，卒莱諭文 束京大学. 1963.

46) Williams, P.P., R. E. Davis, R. N. Doetsch, and J. Gutierrez, Appl Microbiol 9: 405-409. 1961.

47) Gutierrez, J., and R. E. Davis, Appl Microbiol 10: 305-308. 1962.

48）高橋誼身・粕川照男，明大農研報 13：1-6. 1962.

49) Abou Akkada, A.R, and B. H. Howard, Biochem J 82: 313-320, 1962.

50) Gutierrez, J., Biochem J 60: 516-522. 1955.

51）小野寺良次・神立 誠, 日畜会報 39：206-211. 1968.

52) EL-Shazly, K., Biochem J 51: 647-653. 1952.

53) Sirotnak, F. M., R. N. Doetsch., R. E. Brown, and J.C. Show, J Dairy Sci 36: 1117-1123. 1953.

54) Lewrs, D., Brit J Nutr 9: 215-230. 1955.

55) Warner, A.C.I., J Gen Microbiol 14: 749-762. 1956.

56) Van den Hende, C., W. Oyaért, and J. H. Bouc KAERT, Zbl Vet Med 6: 681-692. 1959.

57) Hoshino, S., and Y. Hrrose, J Dairy Sci 46: 323-326. 1963.

58) Bryant, M. P., and I. M. Robinson, J Dairy Sci 46：150-154. 1963.

59）小野寺良次・神立 誠，日畜会報 40：205-211。 1969.

60）小野寺良次，博士論文 東京大学. 1967.

61) Coleman, G. S., J Gen Microbiol 47: 449-464. 1967.

62) Eberlein, R., $Z$ Wiss Zool 59: 233-304. 1895.

63) Liebetanz, E., Arch Protistenk 19: 19-80. 1910.

64) Dogiel, V.A., Quant J Microscop Sci 88: 337343. 1947.

65) Lubinsky, G., Can J Zool 35: 579-580. 1957.

66) Oxford, A. E., J Gen Microbiol 5: 83-90. 1951.

67) Abou Akkada, A.R., and B.H Howard, Biochem J 76: 445-451. 1960.

68) Williams, P. P., J. Gutierrez, and R. N. Doet$\mathrm{scH}$, Proc Soc Am Bacteriologists, Ann Meeting. p. 32. 1960.

69）小野寺良次・神立 誠, 日蓄会報 41：14-21. 1970 .

70) LubinskY, G., Can J Zool 35: 141-159. 1957.

71) Muller, M., P. Röhlich, and I. Törö, J Protozool 12: 27-34, 1965.

72) Gutierrez, J., J Protozool 5: 122-126. 1958.

73) Gutierrez, J., and R. E. Davis, J Protozool 6: 222-226. 1959.

74) Minato, H., A. Ueki, and T. Suto, Proceeding of the First Intersectional Congress of IAMS 2: 187-196, 1974.

75）小野寺良次・神立 誠，日畜会報 41：307-313. 1970.

76) Chalmer, M. I., D. P. Cutheertson, and R. L. M. SYNGE, J Agr Sci 44: 254-262. 1954.
77) 久保辰雄・神立 誠, 日本蓄産学侌大会講演 1965 .

78) Onodera, R., Y. Toyofuku, S. Fujita, S. NakaHaRA, and M. KandatsU, Jap J Zootech Sci 45 : 652-656. 1974.

79) Coleman, G.S., J Gen Microbiol 47: 433-447. 1967.

80) Coleman, G.S., and F.J. Hall, Tissue and Cell 1: 607-618. 1969.

81) Warner, A. C. I., Program-Handbook: IV International Symposium on Ruminant Physiology p. 45. Sydney, 1974.

82) Coleman, G.S., J Gen Microbiol 57: 303-332. 1969.

83) Onodera, R., and M. Kandatsu, Agr Biol Chem 36: 1989-1995. 1972.

84）神立 誠・高橋直身, 日畜会報 34: 148-155. 1963.

85) Ueda, Y., R. Onodera, and M. Kandatsu, Jap J Zootech Sci 46: 34-41. 1975.

86）小野寺良次・神立 誠，日畜会報 侮時增刊学会号 p. 29. 1971.

87) Chesters, J. K., J Protozool 15: 509-512. 1968.

88) Hoshino, S., and S. Sugryama, Comp Biochem Physiol 48B: 39-45. 1974.

89) Coleman, G.S., J Gen Microbiol 35: 91-103. 1964.

90) CoLeman, G. S., J Gen Microbiol 49: 315-323. 1967.

91) Coleman, G.S., J Gen Mic-obiol 71: 117-131. 1972.

92) HaRmeyer, J, Z Tierphysiol Tierernaehr Futtermittelk 28: 65-75. 1971.

93) Sugden, B., and A. E. Oxford, J Gen Microbiol 7: 145-153. 1952.

94) Sugnen, B., J Gen Microbiol 9; 44-53. 1953.

95) Heald, P. J., and A.E. Oxford, Biochem J 53: 506-512. 1953.

96）神立 誠・高憍直身, 日㹃化誌 29：833-838. 1955.

97) Coleman, G.S., J Gen Microbiol 22: 555-563. 1960.

98) Clarke, R. T. J., J Gen Microbiol 33: 401-408. 1963.

99) MAH, R.A., J Protozool 11: 546-552. 1964.

100）小野寺良次・神立 誠，日畜会報 41：343-348. 1970.

101）小野寺良次・神立 誠，日畜会報 41：349-357. 1970.

102）小野寺良次・神立 誠，日音会㪕 44：举会号。 p. 109.1973.

103）小野寺泉次・後藤正博・堤和加夫・神立 誠，日 畜会報 45：学会号. p. 33. 1974.

104) Harmeyer, J., $Z$ Tierphysiol Tierernaehr Futtermittelk 28: 75-85. 1971.

105) Onodera, R., and M. Kandatsu, Agr Biol Chem 33: 113-115. 1969.

106) Zacharius, R. M., J.F. Thompson, and F. C. 
StEward, J Am Chem Soc 74: 2949. 1952.

107) Rothstein, M., and L. L. Miller, J Am Chem Soc 75: 4371-4372. 1953.

108) Grove, J. A., T. J. Gilbertson, R. H. Hammerstedt, and L. M. Henderson, Biochim Biophys Acta 184: 329-337. 1969.

109) Rothstein, M., and E. M. Suffran, Arch Biochem Biophys 101: 373-377. 1963.

110) Miller, D. L., and V.W. Rodweld, J Biol Chem 246: 2758-2764. 1971.

111) Dohner, P. M., and B. P. Cardon, J Bacteriol 67: 608-611. 1954.

112) LewIS, T. R., and R.S. EMERY, J Dairy Sci 45: 1363-1368. 1962.

113) Onodera, R., and M. Kandatsu, Agr Biol Chem 36: 1563-1569. 1972.

114) Voge L, H. J., "Evolving Genes and Proteins" ed. by V. Bryston, and H. J. Voged, 25. Academic Press. New York. 1965.

115) Guttman, H. N., J Protozool 14: 267 271. 1967.

116) Harmeyer, J., und H. Hekimoglu, Zbl Vet Med A 15: 242-254. 1968.

117) Onodera, R., and M. Kandatsu, Nature New Biol 244: 31-32, 1973.

118) Onodera, R., and M. Kandatsu, Agr Biol Chem 38: 913-920. 1974.

119) Tsutsumi, W., R. Onodera, and M. Kandatsu, Agr Biol Chem 39: 711-714. 1975.

120）堤和加夫・小野寺良次・神立 誠，日本農芸化学 会大会講演要旨集 49:407. 1974.

121）小野寺良次・三浦和也塩村範秀・神立 誠, 日 本農芸化学会西日本支部第 135 回大会講演要旨集 p. 13. 1972.

122) Work, E., and D. L. Dewey, J Gen Microbiol
9: 394-406. 1953.

123) Ghuysen, J. M., Bacteriol Rev 32: 425-464. 1968.

124) Osborn, M.J., Ann Rev Biochem 38: 501-538. 1969.

125) Weller, R. A., F. V. Gray, and A. F. Pilgrim, Brit J Nutr 12: 421-432. 1958.

126) Salton, M.R.T., and J.G. Pavlik, Biochim Biophys Acta 39: 398-407. 1960.

127) Hoogenraad, N. J., and F. J. R. Hird, J Gen Microbiol 62: 261-264. 1970.

128) Mason, V.C., and F. White, J Agr Sci 77: 91 98. 1971.

129) Allison, M. J., "Physiology of Digestion and Metabolism in the Ruminant" ed. by A.T. Phillipson, 456-473. Oriel Press. Newcastle upon Tyne. 1970.

130) Gutierrez, J., and R. E. Hungate, Science 126: 511. 1957.

131) Gutierrez, J., J Protozool 6: 21-22. 1959.

132) Coleman, G.S., J Gen Microbiol 37: 209-223. 1964.

133) Wallis, O. C., and G.S. Colmman, J Gen Microbiol 49: 315-323. 1967.

134) Pearson, H. A., Appl Microbiol 17: 819-824. 1969.

135) Weidel, W., and H. Plezer, Adv Enzymol 26: 193-232. 1964.

136) Onodera, R., T. Shinjo, and M. Kandatsu, Agr Biol Chem 38: 921-926. 1974.

137) Klopfenstein, T. J., D. B. Purser, and W.J. TYZNIK, J Anim Sci 25: 765-773. 1966.

138) Purser, D. B., T.J. Klopfenstein, and J.H. Cline, J Nutr 89: 226-234. 1966. 